\title{
JAKA NORMATYWNOŚĆ PO „ŚMIERCI BOGA”? ETYCZNE IMPLIKACJE MYŚLI SŁABEJ
}

\begin{abstract}
Streszczenie. Głównym celem artykułu jest analiza pojęcia normatywności w filozofii myśli słabej Gianniego Vattima. Myśl słaba oznacza teorię osłabienia bycia w epoce końca metafizyki oraz zakwestionowanie kartezjańskiej koncepcji podmiotu. Tego rodzaju teoria filozoficzna nie rezygnuje całkowicie z normatywności w wymiarze moralnym. Vattimo proponuje normatywność słabą, perswazję, bez roszczeń do powszechnej obowiązywalności. Normatywność słaba wyrasta z dialogu i szacunku do tradycji, zaleca respektowanie konkretnych zasad moralnych, ale nie uznaje zobowiązań etycznych o charakterze uniwersalnym. Taka wersja normatywności znajduje swoje uzasadnienie na gruncie dziedzictwa kulturowego, zgody i kontraktu społecznego.
\end{abstract}

Słowa kluczowe: myśl słaba, myśl mocna, natura ludzka, moralność, nihilizm, wolność, prawo naturalne, dziedzictwo kulturowe, etyka postmetafizyczna

1. Wprowadzenie. 2. Od „śmierci Boga” do myśli słabej. 3. Negacja pojęcia natury. 4. Dziedzictwo kulturowe jako źródło moralności. 5. Podsumowanie.

\section{WPROWADZENIE}

W latach 60. ubiegłego wieku rozpoczął się w wielu krajach renesans myśli Fryderyka Nietzschego. Nietzsche-Renaissance wpłynął bardzo głęboko na filozofię uprawianą m.in. we Włoszech. W kraju nad Tybrem, bezpośrednio po II wojnie światowej, nie było łatwo mówić i pisać pozytywnie o autorze Tako rzecze Zaratustra, ponieważ był on bardzo często kojarzony z narodzinami faszyzmu i narodowego socjalizmu. Z biegiem lat podejście Włochów do Nietzschego uległo gruntownej zmianie, głównie za sprawą recepcji twórczości Martina Heideggera, kwestionującej wiele błędnych i uproszczonych sposobów rozumienia myśli Nietzschego. W 1964 r. ukazało się w kraju 
nad Tybrem wydanie krytyczne wszystkich dzieł autora Tako rzecze Zaratustra, które przyczyniło się do wzrostu zainteresowania jego twórczością.

Jednym z włoskich myślicieli, którzy w latach 60 . XX wieku podjęli nowe badania nad dziełem Nietzschego, był Gianni Vattimo (ur. 1936). W wielu kręgach ten autor, związany z Uniwersytetem w Turynie, uchodzi za jednego z najbardziej popularnych myślicieli europejskich i jednego z najważniejszych przedstawicieli filozoficznego postmodernizmu. Jest też najbardziej znanym teoretykiem myśli słabej (pensiero debole) oraz ważnym badaczem fenomenu nihilizmu. Odwołując się do myśli Fryderyka Nietzschego i Martina Heideggera, filozof $z$ Turynu wypracował jeden ze współczesnych modeli etyki postmetafizycznej, który uznaje współczucie i miłosierdzie za centralne kategorie moralne.

Jak rozumieć pojęcie „śmierci Boga” w interpretacji Gianniego Vattima? W czym tkwi istota jego koncepcji myśli słabej? Czy w dobie rewolucji biotechnologicznej można obronić tradycyjne rozumienie natury ludzkiej i prawa naturalnego? Jak uzasadnić normatywność bez fundamentu natury? Czy dziedzictwo kulturowe może być źródłem normatywności? Jak oceniać normatywność ugruntowaną na fundamencie myśli słabej? Głównym celem artykułu jest ukazanie specyfiki normatywności, wyrastającej z filozofii myśli słabej, oraz przedstawienie zastrzeżeń dotyczących uzasadniania norm moralnych w oparciu o dziedzictwo kulturowe, zgodę i kontrakt społeczny.

\section{OD „ŚMIERCI BOGA" DO MYŚLI SŁABEJ}

Kategorię „śmierci Boga” wprowadził do domeny publicznej Fryderyk Nietzsche. Jakie jest podstawowe znaczenie tego pojęcia? Stanowi ono swego rodzaju obraz, który ma symbolizować rozpad fundamentu metafizycznego naszej kultury oraz zanik tradycyjnych wartości moralnych. Dla Nietzschego ta przejmująca metafora stała się nicią Ariadny, dzięki której można się poruszać po labiryncie współczesnej 
kultury i adekwatnie diagnozować najważniejsze problemy naszej epoki historycznej. „Śmierć Boga” to przede wszystkim rozpad tradycyjnej metafizyki oraz koniec wiary w obiektywny porządek świata, który usprawiedliwiałby wierność prawdzie i zasadom moralnym niezależnie od miejsca, czasu i okoliczności.

Nietzsche używa wielokrotnie sformułowania „Bóg umarł” (der Gott ist tot) w swoim dziele Tako rzecze Zaratustra. Jego zdaniem, Bóg, w którego wierzą chrześcijanie, nie jest Bogiem prawdziwym. Dlatego „śmierć Boga” nie oznacza de facto unicestwienia Boga realnie istniejącego, ale jedynie śmierć boskości powołanej do istnienia przez człowieka. W tej perspektywie to człowiek jest stwórcą Bytu Najwyższego. Pisał Nietzsche: „Bóg jest domniemaniem: lecz ja pragnę, aby domniemania wasze nie sięgały dalej, niźli wasza wola twórcza. Bóg jest domniemaniem: lecz ja pragnę, aby domniemania wasze nie wykraczały poza to, co jest do pomyślenia”" Dla autora Tako rzecze Zaratustra umarły Bóg był tym, który jako bezwzględny władca kontrolował człowieka i nie pozwalał na samodzielne i wolne życie ludzi. Wraz ze „śmiercią Boga” przestał istnieć transcendentny „nakazodawca”, który bezwzględnie egzekwował przestrzeganie przez człowieka stałych i niezmiennych norm moralnych.

Zdaniem Nietzschego, tego rodzaju Bóg, wszechobecny i wszechmogący, musiał umrzeć, aby człowiek mógł rozpocząć nowe życie. „On jednak - umrzeć musiał: oczyma, które wszystko widzą - widział człowiecze głębie i dna, całą jego zatajoną sromotę i szpetność. (...) On zawsze mnie widział: na takim świadku zemstę wywrzeć musiałem - lub też sam przestać żyć. Bóg, co widział wszystko, nawet i człowieka, Bóg ten umrzeć musiał! Człowiek nie ścierpi, aby taki świadek ży!!"2. Dla autora Tako rzecze Zaratustra rozpad Boskiego fundamentu - gwarantującego światu porządek, stabilność i uniwersalne zasady moralne - oznacza początek nowej ery wolności,

1 F. Nietzsche, Tako rzecze Zaratustra, tłum. z niem. W. Berent, Warszawa 1990, 99.

2 Tamże, 329-330. 
którą dobrze wyraża następujący fragment z dzieła Radosna wiedza: „My, filozofowie i »duchy wolne«, czujemy się na wieść, że »Bóg umarł«, jakby opromienieni nową jutrzenką; serce nasze przelewa się z wdzięcznością, zdumieniem, przeczuciem, oczekiwaniem w końcu ukazuje się nam widnokrąg znów wolny, chociażby nawet nie był jasny, wreszcie znów mogą wybiegać okręty nasze"3.

Gianni Vattimo rozwinął koncepcję „śmierci Boga”, tworząc kategorię myśli słabej, którą można potraktować jako jedną z możliwych interpretacji myśli Nietzschego. Myśl słaba wyrasta z negacji myśli mocnej (pensiero forte). Myśl mocna to przede wszystkim wiedza typowa dla tradycji metafizycznej Zachodu, która dążyła do określenia spójnej, monolitycznej, stabilnej i niezmiennej struktury rzeczywistości tout court. W tym kontekście chodzi o poznanie - jak twierdzi Vattimo - ufundowane na „błędzie Platona”, który polega na tym, że byciu przypisujemy charakter wieczności i stabilności. W konsekwencji świat naszej konkretnej egzystencji zostaje spustoszony i pozbawiony wartości. Dla myśli mocnej poznanie oznacza przede wszystkim szukanie prawdy jako niezależnego i stabilnego punktu odniesienia, który jest pewny i bezpieczny dla wszystkich ${ }^{4}$. Różne formy myśli mocnej abstrahują od wymiaru afektywnego i interpretacyjnego ludzkiej podmiotowości, przywołując Prawdę, Życie, Rzeczywistość, Historię i Podmiot jako kategorie absolutne o charakterze dogmatycznym.

Zmierzch myśli mocnej oraz narodziny myśli słabej w ujęciu filozofa z Turynu zbiegają się w czasie z końcem nowoczesności i początkiem narodzin epoki ponowożytnej. Warto w tym miejscu podkreślić, że myśl słaba pozostaje $\mathrm{w}$ harmonii $\mathrm{z}$ podstawowymi paradygmatami kultury postmodernistycznej, która postrzega dywersyfikację, rozczłonkowanie, różnorodność i niestabilność jako

3 F. Nietzsche, Radosna wiedza, tłum. z niem. M. Łukasiewicz, Gdańsk 2008, 288.

4 Por. A. Dal Lago, P.A. Rovatti, Elogio del pudore. Per un pensiero debole, Milano 1989, 9-22. 
pozytywne i konstytutywne elementy rzeczywistości5. W konsekwencji nie należy dążyć do tego, aby z góry czy z zewnątrz doprowadzić do ich ujednolicenia czy też wypracowania hierarchii ważności. Postmodernistyczna różnorodność zawiera w sobie możliwość fragmentaryzacji rzeczywistości i uznania jej niemierzalności. Zerwanie z przeszłością prowadzi do regionalizacji różnych dziedzin wiedzy i porzucenia tradycyjnych kanonów kulturowych 6 .

Vattimo twierdzi, że myśl słaba jest koncepcją, która ma świadomość własnych ograniczeń i dlatego porzuca roszczenia wielkich globalnych wizji metafizycznych - jest przede wszystkim teorią osłabienia konstytutywnego charakteru bycia w epoce końca metafizyki Myśl słaba to filozofia, która odrzuca pewność, aby zdobyć wolność. W tym sensie jest typowym przykładem filozofii postmodernistycznej. Tego rodzaju myślenie filozoficzne oznacza, że niedostępność i skrywanie się bycia nie powinny być przyczyną naszego smutku czy rozpaczy, lecz warunkiem właściwego odczytywania naszej ludzkiej kondycji i tworzenia przyjacielskiej relacji z innymi osobami.

\section{NEGACJA POJĘCIA NATURY}

Ważnym elementem koncepcji myśli słabej jest odrzucenie pojęcia natury. W 2006 r. na łamach miesięcznika filozoficznego MicroMega została opublikowana ciekawa dyskusja Gianniego Vattima z dwoma znanymi włoskimi naukowcami na temat początku życia, ewolucji, darwinizmu i ewolucjonizmu biologicznego ${ }^{8}$. Luigi Luca Cavalli-Sforza i Francesco Cavalli-Sforza zaprezentowali w tej debacie stanowisko współczesnej genetyki i biologii, natomiast Vat-

5 Por. P. Duchliński, A. Kobyliński, R. Moń, E. Podrez, O normatywności w etyce, Kraków 2015, 253-287.

6 Por. G. Vattimo, Vocazione e responsabilità del filosofo, Genova 2000, 76-77.

7 Por. G. Vattimo, Della realtà: fini della filosofia, Milano 2011.

8 Por. G. Vattimo, L.L. Cavalli-Sforza, F. Cavalli-Sforza, Scienza o filosofia?, MicroMega 20(2006)1, 7-24. 
timo - broniąc prymatu filozofii nad badaniami naukowymi - ukazał podejście filozoficzne do wielu problemów związanych z ewolucją i dokonującą się na naszych oczach rewolucją biotechnologiczną.

Jeden w ważnych wątków tej dyskusji dotyczył pojęcia natury. Vattimo potwierdził w trakcie debaty swoje wcześniejsze stanowisko, że pojęcie natury jest mitologiczne (mitologico) i ryzykowne (rischioso). Mitologiczny charakter natury polega na tym, że jest ona czystą ideą, pozbawioną realnej treści - ideą odziedziczoną z przeszłości i przyjmowaną bezkrytycznie przez kolejne pokolenia. Natomiast ryzyko związane $\mathrm{z}$ naturą polega na tym, że w niektórych prądach myślowych przypisuje się jej charakter normatywny - gdy jest traktowana jako norma narzucająca nam konkretne zobowiązania moralne. Aby uniknąć rzekomego „zagrożenia” ze strony normatywnej natury, należy ją odrzucić en bloc. Tego rodzaju negacja dotyczy przede wszystkim natury ludzkiej jako struktury normatywnej, która może nas ukierunkować na podjęcie takich a nie innych decyzji moralnych.

Filozof z Turynu twierdzi, że pojęcie natury ma charakter czysto kulturowy. Co więcej, naturze rzekomo bliżej do nie-bycia niż bycia, ponieważ jest ona całkowicie podporządkowana człowiekowi oraz podlega manipulacji ze strony nauki i techniki. Zagrożenie manipulacją dotyczy szczególnie współczesności, w której człowiek technologiczny wprowadza do świata naturalnego „tyranię" tworzonych przez siebie praw i zasad. W konsekwencji dzieje naszej cywilizacji zostały zdominowane nie przez to, co naturalne, ale przez to, co sztuczne i wytworzone przez człowieka. Obecnie nie mamy pewności, czy różnego rodzaju systemy naturalne, które odziedziczyliśmy po naszych przodkach, są dzisiaj konieczne dla naszego biologicznego przetrwania. Przeciwnie, mamy wysoko rozwinięte technologie, które pozwalają nam wytworzyć wszystko w sposób sztuczny. Co więcej, filozof z Turynu twierdzi, że dzięki nauce, technice i nowoczesnym technologiom możemy zastąpić naszymi wytworami dawny porządek naturalny - bez jakiejkolwiek szkody dla przetrwania naszego gatunku. 
Vattimo stanowczo odrzuca przekonanie, że natura posiada jakąkolwiek normatywność pierwotną i absolutną, która wyznacza podstawy etyki normatywnej - nie jest prawdą, że natura warunkuje i określa nasze wybory i decyzje moralne. Dla filozofa z Turynu nie ma żadnej interferencji między światem naturalnym i światem moralnym. „Jedyną wartością, jaką uznaję - twierdzi Vattimo - jest moja dusza, tzn. moja wolność, moje sumienie moralne, moja decyzja, aby kochać bliźniego zamiast go nienawidzić. I chciałbym, aby to właśnie przetrwało w świecie" . Wolność, o której pisze ten myśliciel, ma charakter kulturowy i technologiczny, a nie naturalny czy metafizyczny. Dla tak rozumianej wolności nie istnieje żadna obiektywna granica transformacji człowieka. W konsekwencji należy odejść od rzekomo fałszywej antytezy natura-kultura i zacząć myśleć o tym, że wszystko jest tylko historią.

Filozof $\mathrm{z}$ Turynu twierdzi, że $\mathrm{w}$ momencie naszych narodzin jesteśmy „wrzuceni” w kondycję historyczną, która nas określa, jeśli nawet nie dokonuje się to według praw czysto mechanicznych. Do dzisiaj owo „wrzucenie” w historię stanowiło tylko i wyłącznie przeznaczenie, które można było jedynie przyjąć i zaakceptować. Obecnie możemy to świadomie zmieniać. Jesteśmy wezwani do tego, aby tworzyć prawa i organizować zachowania naprawdę wolne, czyli niezależne od jakichkolwiek uprzednio istniejących zasad i norm. W ujęciu twórcy myśli słabej współczesna rewolucja biotechnologiczna jest przejawem tak rozumianej wolności ${ }^{10}$.

Podkreślając dynamiczne rozumienie bytu ludzkiego, Vattimo odwołuje się m.in. do filozofa Giovanniego Pico della Mirandoli jednego z największych przedstawicieli renesansowego platonizmu włoskiego. Był on tym myślicielem, który twierdził, że jedyną istotą człowieka jest nieposiadanie żadnej istoty. Opisywał człowieka jako

9 Tamże, 22.

10 Por. G. Vattimo, Credere di credere. È possibile essere cristiani nonostante la Chiesa?, Milano 1996, 1999², 70-75. 
byt, któremu Bóg nie przypisał żadnej określonej natury, przeciwstawiał się ujmowaniu człowieka jako mikrokosmosu, który odzwierciedla różnego rodzaju natury obecne we wszechświecie. Przekonywał, że godność człowieka znajduje swój fundament w jego wolności. Pico della Mirandola twierdził, że osoba ludzka nie ma określonego raz na zawsze miejsca we wszechświecie, ale została stworzona w ten sposób, żeby stawać się tym, kim chce: istotą ziemską albą niebiańską, stworzeniem śmiertelnym albo nieśmiertelnym. W konsekwencji na człowieku spoczywa obowiązek, aby nadać sobie samemu własną istotę ${ }^{11}$.

W swoich analizach dotyczących natury ludzkiej Vattimo nawiązuje także do szkockiego myśliciela Davida Hume'a. Potwierdza słuszność „prawa Hume'a”, zgodnie z którym nie wolno przechodzić od opisu pewnego stanu rzeczy do formułowania zasad o charakterze moralnym. Zdaniem filozofa z Turynu, odwoływanie się w argumentacji etycznej do kategorii prawa naturalnego prowadzi do naturalizmu, który jest autorytarny i antydemokratyczny; jeśli w debacie politycznej mamy jakąś prawdę, która jest uzasadniana w sposób naturalny, podważamy tym samym zasadę wolności i demokratycznego współżycia ludzi.

Każda moralność, która nie respektuje „prawa Hume'a”, jest moralnością nacechowaną przemocą. Dotyczy to także tradycyjnej moralności chrześcijańskiej, która odwołuje się do uzasadnienia metafizycznego norm i wartości. Przemoc metafizyczna wpływa na jej wiele aspektów. Filozof z Turynu twierdzi, że tradycja prawa naturalnego oczywiście bardzo często sprzeciwiała się stosowaniu przemocy, ale były też sytuacje, w których służyła jej legitymizacji12.

W tym miejscu warto podkreślić, że Vattimo formułuje niezwykle ostre zarzuty pod adresem Kościoła katolickiego i jego nauczania

11 Por. G. Pico della Mirandola, De hominis dignitate, Heptaplus, De ente et uno e scritti vari, tekst łaciński i tłumaczenie na języki włoski, Firenze 1942.

12 Por. G. Vattimo, Dopo la cristianità. Per un cristianesimo non religioso, Milano 2002, 120. 
moralnego. Oskarża tę instytucję o błędy filozoficzne, homofobię, wrogą wobec człowieka moralność seksualną itp. Jego zdaniem, największym błędem, który coraz bardziej oddala ludzi od katolicyzmu i zdradza pierwotnego ducha Ewangelii, jest odczytywanie prawd ewangelicznych w świetle filozofii obiektywizującej (filosofia oggettivante), która usiłuje stać na straży niezmiennej w czasie natury człowieka i broni kategorii prawa naturalnego. Zdaniem tego myśliciela, czyniąc tak, Kościół katolicki niszczy samą istotę chrześcijaństwa. Dlaczego? Ponieważ w imię natury ludzkiej i prawa naturalnego ignoruje przykazanie miłości bliźniego. Filozof z Turynu odrzuca jakąkolwiek naturalną istotę człowieka, społeczeństwa czy rodziny. Jego zdaniem rewolucyjna nowość chrześcijaństwa polega na odrzuceniu kategorii o charakterze obiektywnym, umieszczając w centrum wolność, jednostkowość i wymiar wewnętrzny każdego człowieka.

Vattimo twierdzi, że chrześcijaństwo wprowadziło w świat zasadę radykalnej odnowy metafizyki klasycznej: odejście od skierowania uwagi na przedmiocie, na przyjętych formach naturalnych jako stałych i wiecznych, które traktuje się jako źródło zasad moralnych; nowe spojrzenie ukierunkowane na wolność i sferę wewnętrzną człowieka. Jego zdaniem, obiektywny charakter praw natury jest mitem. Poważny błąd katolicyzmu polega na połączeniu wiary chrześcijańskiej z obiektywnością praw naturalnych i zbudowaniu na tym fundamencie etyki seksualnej. W tej perspektywie obiektywne prawa natury są niczym innym jak naturą rozumianą przez społeczeństwo w minionych epokach uznanych za archetypy, utożsamiając je z wieczną prawdą o człowieku i społeczeństwie.

$\mathrm{Z}$ jednej strony, filozof $\mathrm{z}$ Turynu bardzo ostro krytykuje katolicyzm z powodu nauczania moralnego, dotyczącego życia indywidualnego i etyki seksualnej, z drugiej - docenia chrześcijańską etykę społeczną i zaangażowanie katolików w życiu publicznym. W tym miejscu warto zauważyć, że w ostatnich latach Vattimo nawiązuje bardzo często w swoich badaniach filozoficznych do tradycji kulturowej Ameryki Południowej. Uważa, że ten kontynent 
ma charakter postmodernistyczny i dlatego stanowi alternatywę dla zachodniego stylu życia. Filozof $z$ Turynu jest wielkim zwolennikiem południowoamerykańskich ruchów ludowych i wiąże z nimi nadzieję na przeprowadzenie koniecznych reform społecznych i politycznych.

W opinii Vattima i liderów tych ruchów głównymi wrogami ludzkości są dzisiaj globalizacja, kulturowy europocentryzm i władza nad światem sprawowana przez globalny system finansowy. W tej nowej walce klas XXI wieku środowiska lewicowe powinny połączyć swoje siły z kręgami katolickimi. W tym sensie Ameryka Południowa, posiadająca specyficzne rozumienie religijności i chrześcijaństwa, jest swego rodzaju laboratorium, w którym wykuwa się nowy świat postulowany przez filozofa z Turynu.

Czym jest natura dla Vattima? Jego zdaniem, nazywamy naturą to, co jest jedynie naszym starym przyzwyczajeniem. Przeciwstawiamy się zmianom dokonywanym w imię natury, która nie istnieje, a w rzeczywistości wszyscy uczestniczymy w tego rodzaju zmianach. Twórca koncepcji myśli słabej zauważa, że w przypadku człowieka trudno ograniczyć naturę ludzką do tego, czym człowiek jest i czym może się stać, pozwalając działać naturze. Naturalne jest to, co takim się wydaje w określonych warunkach egzystencji - jak czymś naturalnym jest odpowiedź na pozdrowienia na ulicy, nawet jeśli żadne prawo metafizyczne nam tego nie narzuca. To naturalne kryterium powinno obowiązywać dzięki prawom ustanowionym w ramach demokratycznego porządku politycznego ${ }^{13}$.

Vattimo, odrzucając naturę ludzką i wynikające z niej prawo naturalne, promuje jednocześnie wolność, interpretując naturę jako kategorię konkurencyjną i przeciwstawną wobec wolności i sfery wewnętrznej człowieka. Błąd filozofa z Turynu polega na statycznym i biologicznym ujęciu natury ludzkiej - przy takiej interpretacji bytu ludzkiego trudno oczywiście o zachowanie właściwej wizji wolności

13 Por. G. Vattimo, La vita dell'altro. Bioetica senza metafisica, Lungro di Cosenza 2006, 43-44. 
człowieka. Vattimo należy do grona tych autorów, którzy odrzucają kategorię natury z powodu przyjęcia absolutnego i abstrakcyjnego pojęcia wolności, rozumianej jako uwolnienie od tego wszystkiego, co nie zostało określone przez samą wolność. W konsekwencji dotyczy to również uwolnienia od natury. Natura ludzka nie oznacza jednak czystej obiektywności pasywnej materii, ale także tożsamość racjonalną, która wyrasta z różnych doświadczeń człowieka jako bytu zanurzonego w historii.

Vattimo zgadza się z bardzo ogólnym rozumieniem natury ludzkiej, prowadzącym do wspólnej troski o to, aby np. nie traktować ludzkiego ciała jako przedmiotu, którym można handlować. Tego rodzaju podejście do natury ludzkiej ma na celu ochronę godności człowieka w dobie rewolucji biotechnologicznej. Filozof z Turynu ujmuje naturę ludzką przede wszystkim metaforycznie, jako formę zatroskania o ochronę naszej człowieczej godności ${ }^{14}$. W analizach antropologicznych tego autora nie znajdujemy odniesień do innych ważnych myślicieli, którzy prezentują zdecydowanie odmienne wizje natury ludzkiej. Warto w tym miejscu wskazać cenne opracowania włoskiego filozofa Vittoria Possentiego ${ }^{15}$ czy ważne prace niemieckiego myśliciela Roberta Spaemanna ${ }^{16}$. Niestety, filozof z Turynu pomija ciekawą argumentację tych autorów całkowitym milczeniem.

\section{DZIEDZICTWO KULTUROWE JAKO ŹRÓDŁO MORALNOŚCI}

$\mathrm{Z}$ jednej strony, twórca koncepcji myśli słabej wyraża przekonanie, że z natury człowieka nie możemy wyprowadzić jakichkolwiek norm czy praw moralnych. Skoro do istoty człowieka należy posiadanie historii, tworzenie kultury i technologii, to należy odrzucić wszelką normatywność związaną z kategorią natury ludzkiej. Z drugiej strony,

14 Por. tenże, Dopo la cristianità, dz. cyt., 87.

15 Por. V. Possenti, II nuovo principio persona, Roma 2013.

16 Por. R. Spaemann, Szczęście a życzliwość: esej o etyce, tłum. z niem. J. Merecki, Lublin 1997. 
Vattimo twierdzi, że nie możemy zgodzić się na całkowity relatywizm i anarchię moralną, tzn. potrzebujemy innej formy normatywności nie wszystko wolno, nie każdy czyn jest dozwolony, nie wszystko, co jest technicznie możliwe, musi być moralnie dopuszczalne. Skąd zatem pochodzą normy moralne i w jaki sposób możemy je uzasadnić? Gdzie szukać nowego źródła normatywności? Dla filozofa z Turynu źródłem norm moralnych - decydujących o tym, co jest dopuszczalne, a co zakazane - jest dziedzictwo kulturowe, w którym żyjemy oraz dialog prowadzony w obrębie wspólnej tradycji aksjologicznej ${ }^{17}$.

Vattimo twierdzi, że współczesny zanik dyskursu etycznego w oparciu o zasady uniwersalne i ostateczne ma charakter globalny i wynika głównie $\mathrm{z}$ dominującego pluralizmu kulturowego oraz zmiany relacji Zachodu do innych kręgów kulturowych, które w ostatnich dziesięcioleciach przeszły od stanu kolonialnego do niepodległości i samostanowienia. Zmierzch etyki pierwszych zasad to także owoc krytyki moralności tradycyjnej ze strony trzech wielkich „mistrzów podejrzeń”: Karola Marksa, Fryderyka Nietzschego i Zygmunta Freuda ${ }^{18}$. Tego rodzaju teorie filozoficzne odzwierciedlają głęboką transformację społeczną i kulturową ostatnich dwóch stuleci. Zburzenie pierwszych zasad nie oznacza jednak zgody na etykę sytuacyjną. Mamy tutaj do czynienia z podstawową różnicą między etyką postmetafizyczną a zwykłym i czystym relatywizmem. „Stwierdzenie, że rozpadła się wiarygodność pierwszych zasad uważa Vattimo - nie pozwala się przetłumaczyć na przyjęcie naszej kondycji historycznej i naszej przynależności do wspólnoty jako jedynego absolutu. Jeśli świat prawdziwy (pierwsze zasady) stał się bajką, pisze Nietzsche, zburzeniu uległa także bajka (zatem także ona nie może być absolutyzowana)" 19 .

17 Por. G. Giorgio, II pensiero di Gianni Vattimo. L'emancipazione della metafisica tra dialettica ed ermeneutica, Milano 2006, 239-240.

18 Por. G. Vattimo, Addio alla verità, Roma 2009, 95.

19 Tamże, 98. 
Jak zatem możemy określić normatywność ufundowaną na gruncie myśli słabej? Warto w tym miejscu podkreślić, że normatywność w sferze moralnej składa się z szeregu elementów o charakterze obiektywnym i subiektywnym. Zwracają na to uwage autorzy najnowszych opracowań naukowych, poświęconych tej problematyce ${ }^{20}$. Mamy zasadniczo dwa podstawowe źródła normatywności moralnej, tzn. pewną rzeczywistość i wolę podmiotu. Normatywność jawi się jako pochodna decyzji podmiotu bądź podmiotów, ale jest także zależna od pewnego układu odniesienia, który ,jest rozpoznawany jako najwłaściwszy tu i teraz. Działanie zgodne z jego treścią jest tym, co można byłoby nazwać powinnym (Gesollt), czyli tym, co powinno się zrobić. Takie działanie jest zarazem racjonalne i moralne"21.

Układ odniesienia można nazywać w rozmaity sposób: idealnymi porządkami powinnościowymi, prawem naturalnym, idiomem postępowania, rzeczywistością osoby lub jeszcze inaczej. Ryszard Moń twierdzi, że „od wrażliwości człowieka, od bystrości jego umysłu zależy zatem, jakie podejmie działania lub sposób życia, by uczynić zadość wymaganiom, jakie stawia konkretny układ odniesienia, swoisty idiom postępowania. Normatywność jawi się zatem jako wypadkowa woli szczęśliwego życia oraz racjonalnego idiomu ludzkiej aktywności”22.

Twórca koncepcji myśli słabej podkreśla, że musimy czerpać z dziedzictwa kulturowego i tradycji, do których należymy. Dziedzictwo kulturowe i tradycja to zespół tych wszystkich rzeczy i przedmiotów, w obrębie których - konfrontując się z innymi osobami - dokonujemy naszych wyborów. Wybieramy nie na podstawie kryterium prawdy

20 Por. Ch. Gill, Virtue, Norms and Objectivity: Issues in Ancient and Modern Ethics, Oxford 2005; J.D. Wallace, Norms and Practices, Ithaca 2008; G. Brennan, L. Eriksson, R. Goodin, Explaining Norms, Oxford 2013; E. Colzani, A. Rossetti, Mente, azione, normatività, Milano 2014; Ch. Korsgaard, Le origini della normatività, Pisa 2014.

21 R. Moń, Warto czy należy? Studium na temat istoty i źródeł normatywności, Warszawa 2011, 495-496.

22 Tamże, 543. 
absolutnej, ale na bazie miłości. Wybieramy te interpretacje i rozwiązania, które pozwalają nam patrzeć na drugiego człowieka bez poczucia wstydu: prawda powinna iść w parze $\mathrm{z}$ miłością.

Wsłuchiwanie się w dziedzictwo kulturowe i interpretacja tradycji nie prowadzą tylko i wyłącznie do przewartościowania wszystkich wartości, ale także do odkrycia treści, które dziedziczymy. Wiele reguł, które obowiązują w życiu społecznym, nie zostaje automatycznie zawieszonych bądź zniesionych przez etykę postmetafizyczną. Wiele z nich traktowano wcześniej jako normy naturalne. Uznane natomiast za dziedzictwo kulturowe, a nie za naturę i istotę rzeczy, mogą dalej obowiązywać także w naszej epoce historycznej, ale nie jako normy naturalne, lecz jako normy racjonalne, uznane przez ludzki rozum.

Według filozofa $z$ Turynu, prawda o zburzeniu fundamentu staje się dzisiaj nowym fundamentem. Można rozwijać dyskurs etyczny opierając się na tradycji pochodzenia i dziedzictwie kulturowym, tworzyć maksymy odnoszące się do naszego działania. Można też wypracowywać wskazania określające zachowanie i hierarchię wartości. Przyjęcie za ostateczny punkt odniesienia przynależności bardziej określonych - takich jak rasa, naród, klasa społeczna czy rodzina oznacza ograniczenie u samych źródeł własnej perspektywy etycznej. $Z$ tego rodzaju konkretnych przynależności wypływają zasady odnoszące się do naszego postępowania, ale nie stanowią one imperatywu absolutnego, a jedynie rozszerzenie własnych horyzontów. W ten sposób, w opinii Vattima, pochodzenie i przynależność stają się dla etyki głównym punktem odniesienia.

Jakie maksymy i zachowania możemy wyprowadzić z naszej tradycji, pochodzenia oraz z naszego dziedzictwa kulturowego? Przede wszystkim te nacechowane krytycyzmem. Do tego dochodzi ciągłe wsłuchiwanie się w treści dziedzictwa i pochodzenia, aby nie przeceniać perspektywy przeszłości i zachować świadomość odpowiedzialności w stosunku do własnej tradycji kulturowej. „Słuchanie dziedzictwa - pisze filozof z Turynu - nie prowadzi tylko do 
"przewartościowania« wszystkich wartości, ale także do podniesienia i naśladowania określonych treści, które odziedziczyliśmy"23.

Zasady moralne wywodzące się z dziedzictwa kulturowego i uznane przez nas za normy racjonalne stanowią ograniczoną formę normatywności etyki postmetafizycznej proponowanej przez Vattima. W twórczości filozofa z Turynu nie znajdziemy adekwatnej odpowiedzi na pytanie, co jest treścią i fundamentem powinności moralnej. Nie ma też pogłębionej analizy różnych sposobów pojmowania normatywności. Momentem obiektywnym normatywności etyki postmetafizycznej w ujęciu twórcy myśli słabej jest dziedzictwo kulturowe i podlegająca interpretacji tradycja, natomiast decyzja podmiotu, który uznaje zasady moralne pochodzące $\mathrm{z}$ tradycji za normy racjonalne stanowi jej moment subiektywny ${ }^{24}$.

\section{PODSUMOWANIE}

Etyka postmetafizyczna Gianniego Vattima, zbudowana na gruncie myśli słabej, nie rezygnuje całkowicie z normatywności, ale zachowuje ją w formie ograniczonej. Zasady moralne wywodzące się z dziedzictwa kulturowego i uznane przez nas za normy racjonalne należy uznać za normatywność w wersji słabej. Wydaje się, że w ramach filozofii negującej myśl mocną i będącej kontynuacją dzieła Fryderyka Nietzschego trudno o inną formę etyki normatywnej. Najważniejszą przyczyną niemożliwości wypracowania alternatywnych form normatywności jest odrzucenie przez filozofa z Turynu natury ludzkiej i prawa naturalnego.

Vattimo twierdzi, że w naszej epoce nauka i technika przekształcają naturę w historię. W świecie, w którym wszystko staje się

23 G. Vattimo, Addio alla verità, dz. cyt., 102.

24 Por. A. Kobyliński, O możliwości zbudowania etyki nihilistycznej. Propozycja Gianniego Vattima, Warszawa 2014, 189-196; tenże, Nihilism and Ethics in the Philosophy of Weak Thought of Gianni Vattimo, Seminare. Poszukiwania Naukowe 37(2016)4, 55-67. 
historią, nie ma miejsca na obiektywne normy moralne, ponieważ byt człowieka nie posiada wewnętrznej struktury, z której można wyprowadzić trwałe i niezmienne zasady etyczne. Jedyną etyką możliwą do przyjęcia jest etyka interpretacji. W poszukiwaniu swych własnych indywidualnych zasad postępowania człowiek powinien jedynie interpretować zdarzenia i myśli, czyny i słowa. Tego rodzaju wizja moralności nie oznacza zgody na relatywizm, ponieważ zakłada także normatywność w wersji słabej.

Budzi sprzeciw stosunek Vattima do orędzia chrześcijańskiego i jego głęboka redefinicja podstawowych kategorii moralnych tej religii. Trudno zgodzić się także z postulowanym przez tego autora odrzuceniem natury i prawa naturalnego jako źródła moralności. Niestety, filozof z Turynu ujmuje naturę ludzką przede wszystkim metaforycznie, jako formę zatroskania o ochronę naszej człowieczej godności. Można odnieść wrażenie, że jedną z głównych przyczyn zanegowania natury ludzkiej i prawa naturalnego jest obrona wolności i samorealizacji człowieka. Niestety, twórca myśli słabej nie zauważa, że natura i wolność nie są pojęciami przeciwstawnymi. W rzeczywistości natura ludzka oznacza określone cele, do których dąży byt ludzki w sposób świadomy, racjonalny i wolny.

Wydaje się, że największą słabością normatywności w wersji słabej jest niewielka zdolność do narzucenia podmiotowi moralnemu określonych zachowań. Niemiecki myśliciel Romano Guardini, analizując system etyczny Immanuela Kanta, mówił o problemie „siły zobowiązywania" (die Verpflichtungskraft) ze strony prawdy, dobra i wartości. Guardini uważał, że największym mankamentem autonomicznej wizji moralności jest niewielka siła zobowiązywania nakazów i zakazów określanych przez imperatyw kategoryczny. Analogicznie podobne zastrzeżenia możemy sformułować pod adresem norm moralnych wyprowadzonych $\mathrm{z}$ dziedzictwa kulturowego.

$Z$ jednej strony normatywność w wersji słabej chroni człowieka przez skrajnym relatywizmem $\mathrm{i}$ anarchią moralną, $\mathrm{z}$ drugiej - $\mathrm{w}$ dobie rewolucji biotechnologicznej tego rodzaju normatywność nie 
wystarcza, aby skutecznie bronić gatunek ludzki przed różnymi formami manipulacji i ingerencji w podstawy naszej struktury bytowej. W obliczu obecnych wyzwań cywilizacyjnych tylko powrót do tradycyjnego rozumienia natury ludzkiej może skutecznie chronić ludzką godność i naszą wyjątkowość gatunkową pośród innych organizmów żywych. Przyjęcie dynamicznej koncepcji natury człowieka oraz wskazanie dialogu, porozumienia czy tradycji kulturowej jako źródła norm moralnych tworzy podatny grunt dla różnego rodzaju manipulacji biotechnologicznych i wszelkich prób zmiany istoty naszego człowieczeństwa.

\section{BIBLIOGRAFIA}

Brennan G., Eriksson L., Goodin R., Explaining Norms, Oxford University Press, Oxford 2013.

Colzani E., Rossetti A., Mente, azione, normatività, Ledizioni, Milano 2014.

Dal Lago A., Rovatti P.A., Elogio del pudore. Per un pensiero debole, Feltrinelli Editore, Milano 1989.

Duchliński P., Kobyliński A., Moń R., Podrez E., O normatywności wetyce, Akademia Ignatianum - Wydawnictwo WAM, Kraków 2015.

Gill Ch., Virtue, Norms and Objectivity: Issues in Ancient and Modern Ethics, Oxford University Press, Oxford 2005.

Giorgio G., Il pensiero di Gianni Vattimo. L'emancipazione della metafisica tra dialettica ed ermeneutica, Franco Angeli Editore, Milano 2006.

Kobyliński A., O możliwwości zbudowania etyki nibilistycznej. Propozycja Gianniego Vattima, Wydawnictwo UKSW, Warszawa 2014.

Kobyliński A., Nibilism and Ethics in the Philosophy of Weak Thought of Gianni Vattimo, Seminare. Poszukiwania Naukowe 37(2016)4, 55-67.

Korsgaard Ch., Le origini della normatività, Edizioni ETS, Pisa 2014.

Moń R., Warto czy należy? Studium na temat istoty i zródet normatywności, Wydawnictwo UKSW, Warszawa 2011.

Nietzsche F., Radosna wiedza, tłum. z niem. M. Łukasiewicz, Wydawnictwo Słowo/Obraz Terytoria, Gdańsk 2008.

Nietzsche F., Tako rzecze Zaratustra, tłum. z niem. W. Berent, Biuro Informacji Studenckiej ZSP, Warszawa 1990. 
Pico della Mirandola G., De hominis dignitate, Heptaplus, De ente et uno e scritti vari, tekst łaciński i tłumaczenie na języki włoski, Vallecchi Editore, Firenze 1942.

Possenti V., Il nuovo principio persona, Armando Editore, Roma 2013.

Spaemann R., Szczęście a życzliwoś́: esejo etyce, tłum. z niem. J. Merecki, Redakcja Wydawnictw KUL, Lublin 1997.

Vattimo G., Credere di credere. È possibile essere cristiani nonostante la Chiesa?, Garzanti Editore, Milano 1996, 19992.

Vattimo G., Vocazione e responsabilità del filosofo, Il Nuovo Melangolo, Genova 2000.

Vattimo G., Dopo la cristianità. Per un cristianesimo non religioso, Garzanti Editore, Milano 2002.

Vattimo G., Cavalli-Sforza L.L., Cavalli-Sforza F., Scienza o filosofia?, MicroMega 20(2006)1, 7-24.

Vattimo G., La vita dell'altro. Bioetica senza metafisica, Marco Editore, Lungro di Cosenza 2006.

Vattimo G., Addio alla verità, Meltemi Editore, Roma 2009.

Vattimo G., Della realtà: fini della filosofia, Garzanti Editore, Milano 2011.

Wallace J.D., Norms and Practices, Cornell University Press, Ithaca 2008.

\title{
WHICH NORMATIVITY AFTER THE "DEATH OF GOD”? ETHICAL IMPLICATIONS OF WEAK THOUGHT
}

\begin{abstract}
The main aim of this article is to analyze the concept of normativity in the philosophy of weak thought developed by Gianni Vattimo. Weak thought refers to the idea of the weakening of existence in times witnessing the end of metaphysics, and to a challenge to the Cartesian conception of the subject. This philosophical tradition does not entirely give up on moral normativity. Vattimo proposes a weak notion of normativity, i.e. persuasion, without claims of universal applicability. Weak normativity grows out of dialogue with and respect for tradition, and recommends compliance with specific moral principles. However, it does not consider their applicability to be universal. This kind of normativity is established on the basis of cultural heritage, agreement and social contract.
\end{abstract}

Keywords: weak thought, strong thought, human nature, morality, nihilism, freedom, natural law, cultural heritage, post-metaphysical ethics

\footnotetext{
ANDRZEJ KOBYLIŃSKI

a.kobylinski@uksw.edu.pl

Uniwersytet Kardynała Stefana Wyszyńskiego w Warszawie, Instytut Filozofii

Wóycickiego 1/3, 01-938 Warszawa
}

DOI: 10.21697/spch.2018.54.2.13 